\title{
Biennial bearing in apple cultivars
}

\author{
João Caetano Fioravanço ${ }^{1^{*}}$, Ana Beatriz Costa Czermainski ${ }^{2}$
}

10.1590/0034-737X201865020005

\begin{abstract}
Biennial bearing is the process in fruit trees by which one year of high fruit load is followed by a very low load or no production the next year. In apple growing, this is a troublesome problem, because of the negative effect on crop yield accumulated over the years, fruit quality, and plant physiology. The objective of this study was to evaluate the biennial bearing of nine apple cultivars, grafted on two rootstocks using of the biennial bearing index (BBI). The indices were calculated for the scion cultivars Maxi-Gala, Gala Real, Royal Gala, Fuji Select, Fuji Suprema, Mishima, Daiane, and Cripps Pink based on the yields from the harvests from 2008 to 2013. The apple cultivars exhibited no significant alternate production, considering the range of variation of the index. For the M-9 rootstock, cv. Fuji Suprema showed the highest BBI. For Marubakaido/M-9, Baigent, Mishima, Fuji Select, and Maxi-Gala showed the highest indices. There was no correlation between the biennial bearing index and the stem cross section of the scion cultivars, regardless of the rootstock used.
\end{abstract}

Keywords: Malus x domestica; yield; fruit thinning.

\section{RESUMO}

\section{Alternância de produção de cultivares de macieira}

A alternância de produção caracteriza-se por um ano de elevada carga de frutos, seguido de outro ano com produção muito baixa ou nula. Na cultura da macieira é um problema indesejável, devido ao efeito negativo sobre a produtividade acumulada ao longo dos anos, qualidade da fruta e fisiologia da planta. O objetivo do trabalho foi avaliar a alternância de produção de nove cultivares de macieira, enxertadas sobre dois porta-enxertos, por meio da aplicação do índice de alternância de produção (IAP). A partir das produtividades observadas nas safras 2008 a 2013 , foram calculados os IAP para as cultivares Baigent, Maxi-Gala, Gala Real, Royal Gala, Fuji Select, Fuji Suprema, Mishima, Daiane e Cripps Pink. As cultivares de macieira não apresentaram forte alternância de produção, considerando a amplitude de variação do índice utilizado. No porta-enxerto M-9, a cultivar Fuji Suprema exibiu IAP maior que as demais cultivares. No Marubakaido/M-9, os maiores índices foram apresentados por 'Baigent', 'Mishima', 'Fuji Select' e 'Maxi-Gala'. Não houve correlação entre o índice de alternância de produção e a área transversal do caule das cultivares, independentemente do porta-enxerto utilizado.

Palavras-chave: Malus x domestica; produtividade; raleio de frutos.

\footnotetext{
Submitted on October $29^{\text {th }}, 2014$ and accepted on February $03^{\text {rd }}, 2018$

1 Embrapa Uva e Vinho, Bento Gonçalves, Rio Grande do Sul, Brazil. joao.fioravanco@embrapa.br

2 Embrapa Uva e Vinho, Bento Gonçalves, Rio Grande do Sul, Brazil. ana.czermainski@embrapa.br.

*Corresponding author: joao.fioravanco@embrapa.br
} 


\section{INTRODUCTION}

Biennial bearing in fruit trees is characterized by one year of high fruit load followed by a next year of very low load or no production (Guitton et al., 2012). It occurs in different families and fruit species such as apple, pear, plum, walnut, olive, avocado, mango, and citrus (Monselise \& Goldschmidt, 1982). According to Jackson (2011), biennial bearing involves insufficient flowering and should not be confused with low fruit set, which occurs due to poor pollination.

In the apple crop, biennial bearing is a troublesome problem because of the negative effect on yield accumulated over the years, fruit quality, and plant physiology. However, it is a common problem in many cultivars, including Fuji, Braeburn (Hampson \& Kemp, 2003), Jonagold, Mutsu, Spy, Fortune (Robinson, 2008), Golden Delicious (McArtney et al., 2013), Honey Crisp, Pacif Rose and Elstar (Krasniqi et al., 2013).

The high fruit load in the first two years is considered the main cause of the alternate behavior because it negatively affects the vegetative growth and the flowering of the plant (Smith \& Samach, 2013). In the literature, however, other factors that are potentially capable of causing or contributing to the occurrence of alternate bearing such as the genetic characteristic of the cultivar, the rootstock and its interaction with the cultivar, the biotic and abiotic stresses, the allocation of reserves to the different organs of the plant, the intensity and timing of thinning, and the hormonal balance (Barritt et al., 1997; Bangerth, 2000; Guitton et al., 2012).

Hoblyn et al. (1936) proposed a method that is still used today to estimate biennial bearing in apple trees, based on historical yield data. Crassweller et al. (2005) points out that the Biennial Bearing Index (BBI) is important to guide the appropriate thinning and, thus, to establish the quantity of fruits that each plant or cultivar can bear without inducing alternation and without compromising fruit quality. The use of the index in cultivar competition trials provides information, along with other traits, to differentiate the materials in study. In Brazil, there are reports on the application of the index to evaluate alternation in mandarins (Cantuarias-Avilés et al., 2010) and oranges (Cantuarias-Avilés et al., 2011).

From the foregoing, therefore, the objective of this study was to evaluate the alternate behavior of nine cultivars of apple trees grafted on two rootstocks over six harvests using the biennial bearing index.

\section{MATERIAL AND METHODS}

Yield data from two experimental orchards implanted in 2006 at Embrapa Grape and Wine, Experimental Station of Temperate Fruit Crops, Vacaria, RS, Brazil. The cultivars used were in the experiment were Baigent, MaxiGala, Royal Gala, Royal Gala, Fuji Select, Fuji Suprema, Mishima, Daiane and Cripps Pink. The experiment was arranged in a randomized block design, with three replicates and ten plants per experimental unit. Different rootstocks and spacings were used for each orchard, as follows: a) M-9 (Malus pumila) rootstock, spaced $3.5 \mathrm{mx}$ $1.0 \mathrm{~m}$ (2,857 plants ha-1); and b) Marubakaido ( $M$. prunifolia) rootstock with interstem of M-9, spaced 4.0 mx $1.4 \mathrm{~m}\left(1,785\right.$ plants ha $\left.{ }^{-1}\right)$.

The plants received conventional farm management practices used in the commercial orchards of the region, with minimum pruning in the first 2 years and training in the central leader system. In the planting year, to favor growth, all flowers and fruits were removed. Dormancy break was carried out with 0.2 to $0.25 \%$ hydrogen cyanamide and 3 to $4 \%$ mineral oil. Fertilization and pest and disease control were identical for all cultivars. Thinning was done manually, leaving 1 to 2 fruits per bunch.

Biennial bearing indices (BBI) were calculated using yield data from the harvests 2008-2013, per scion/rootstock combination and per repetition. The variable was fitted to the model $\mathrm{Y}_{\mathrm{ijk}}=\mu+\mathrm{P}_{\mathrm{i}}+\mathrm{C}_{\mathrm{j}}+\hat{\mathrm{a}}(\mathrm{P})_{\mathrm{k}(\mathrm{i})}+(\mathrm{PC})_{\mathrm{ijj}}+\stackrel{\circ}{\mathrm{ijk}}_{\mathrm{j}}$, where $\mathrm{Y}_{\mathrm{ijk}}$ is the response of clone $\mathrm{j}(\mathrm{j}=1$ to 9$)$, in block $\mathrm{k}(\mathrm{k}=1$ to 4$)$, and rootstock $i\left(i=1\right.$ and 2); $i$ is the overall mean; $P_{i}$ is the effect of the rootstock; $\hat{a}(\mathrm{P})_{\mathrm{k}(\mathrm{i})}$ is the effect of block within rootstock; $\mathrm{C}_{\mathrm{j}}$ is the effect of the clone; $\mathrm{PC}_{\mathrm{ij}}$ is the effect of the interaction between rootstock and clone; and $\stackrel{\mathrm{a}}{\mathrm{ijk}}_{\mathrm{j}}$ is the experimental error associated with $\mathrm{Y}_{\mathrm{ijk}}$. The index was calculated by the following equation, adapted from Hoblyn et al. (1936):

$B B I=\sum_{i=2}^{n}\left[\frac{\left|y_{i}-y_{i-1}\right| /\left(y_{i}+y_{i-1}\right)}{(n-1)}\right]$

where $y_{s}$ is the yield observed in the plot, in the $s^{\text {th }}$ crop, in the ordered series of size $n$, where $n$ is the number of harvests; $\left|y_{\mathrm{s}}-\mathrm{y}_{\mathrm{s}-1}\right|$ is the absolute difference between the yields of two successive crops. This index corresponds to the average of the absolute differences between two successive crops expressed as a proportion of the total produced in the two years and varies from zero to one; the closer its value is to one (1), the more pronounced is the alternation or oscillation of production. Noted that in the above expression, for simplification, the indexers for rootstock, cultivar and block were not considered, since it is calculated per experimental plot, that is, $\mathrm{BBI}_{\mathrm{ijk}}=\mathrm{BBI}$. This measure was subjected to the analysis of variance, since the data satisfied the Anova assumptions. The unfolding of the interaction was performed for clone within the rootstock using the Scott-Knott's test $(\mathrm{P} \leq 0.05)$. Based on the same model, the pure correlation between BBI and 
trunk cross-sectional area (TCA), expressed as $\mathrm{cm}^{2}$, was obtained as a measure of plant vigor.

The analyses were performed using the glm procedure in SAS TM (SAS Institute, 2004), which was also used to calculate BBI. The Scott-Knott test to identify similar clones for the same rootstock was performed with the Sisvar computational system (Ferreira, 2011).

\section{RESULTS AND DISCUSSION}

Table 1 shows the mean yields of the apple cultivars, on the rootstocks M-9 and Marubakaido/M-9 replicates, from the harvests 2008-2013, in Vacaria, RS, with numerical oscillations in the period. In the third harvest, reduction occurred only for the Fuji Suprema on Marubakaido/M-9. From the fourth harvest, yield decreases in alternate years for most cultivars. Royal Gala showed a drop in production only in the harvest of 2013. Mishima on Marubakaido/M9 was the only combination showing no yield alternation in the period of evaluation. Since these evaluations are deductive, without a quantitative measure associated with the alternate characteristic, they do not allow the comparison of cultivars, which can be achieved by using an appropriate index.

The analysis of the residues associated with BBI showed no assumption violations in the analysis of variance. We found a significant effect for the cultivar $\mathrm{x}$ rootstock interaction ( $\mathrm{p}=0.003)$, but none for the main effects ( $p>0.05)$. The development of cultivars on the M9 rootstock indicated a greater BBI for Fuji Suprema than for the other cultivars. The rootstock Marubakaido/M-9 showed the highest indices for the cultivars Baigent, Mishima, Fuji Select, and Maxi-Gala (Table 2). Representative curves of mean yields for the scionrootstock combination of the highest and lowest BBI facilitate the visualization of the differences in the oscillation along the harvests (Figure 1).

The inclusion of Fuji Suprema and cultivars Fuji Select and Mishima in different groups, for the M-9 rootstock is unexpected, since cultivars of the Fuji group are considered as alternate (Hampson \& Kemp, 2003; Robinson, 2008). Fuji Suprema, Fuji Select and Mishima are spontaneous mutations of Fuji (Petri et al., 1997; Komatsu, 1998) and, therefore, in theory, they should behave similarly to each other and to their cultivar of origin, regarding the tendency to alternate production, since they were subjected to the same management practices and thinning of fruits. Janick et al. (1996) argued that in apple trees the mutations originate in a cell from which a bud develops and this produces a branch that is different from the others usually in a single characteristic.

The inclusion of Baigent and Maxi-Gala among those with the highest BBI, with the Marubakaido/M-9 rootstock, is also unexpected because they are spontaneous mutations of Imperial Gala and Royal Gala, both belonging

Table 1: Yield ( $\left(\mathrm{ha}^{-1}\right)$ of apple cultivars in the harvests 2008 to 2013, in Vacaria, RS. 2015

\begin{tabular}{|c|c|c|c|c|c|c|}
\hline \multirow{3}{*}{ Cultivar } & \multicolumn{6}{|c|}{ Harvest } \\
\hline & 2008 & 2009 & 2010 & 2011 & 2012 & 2013 \\
\hline & \multicolumn{6}{|c|}{ Rootstock M-9 } \\
\hline Baigent & 6.90 & 10.70 & 49.69 & $47.94^{*}$ & 85.62 & 57.97 \\
\hline Cripps Pink & 4.70 & 22.15 & 41.27 & 55.49 & $\underline{53.21}$ & 69.32 \\
\hline Daiane & 6.65 & 21.95 & 36.75 & 48.95 & $\underline{33.50}$ & 56.29 \\
\hline Fuji Select & 3.61 & 21.69 & 42.95 & $\underline{41.12}$ & 43.64 & 56.27 \\
\hline Fuji Suprema & 2.85 & 21.65 & 28.25 & 48.70 & 25.92 & 64.08 \\
\hline Gala Real & 5.91 & 11.57 & 35.20 & $\underline{29.28}$ & 66.88 & 47.01 \\
\hline Maxi-Gala & 3.46 & 7.21 & 34.99 & 40.79 & 79.88 & $\underline{52.10}$ \\
\hline Mishima & 4.10 & 24.23 & 44.87 & 48.27 & $\underline{42.40}$ & 59.71 \\
\hline Royal Gala & 6.70 & 8.37 & 31.83 & 34.77 & 70.69 & $\underline{38.09}$ \\
\hline \multicolumn{7}{|c|}{ Rootstock Marubakaido/M-9 } \\
\hline Baigent & 3.35 & 12.39 & 48.92 & $\underline{40.73}$ & 75.70 & $\underline{54.43}$ \\
\hline Cripps Pink & 1.81 & 14.01 & 25.10 & 38.77 & $\underline{31.98}$ & 44.53 \\
\hline Daiane & 3.41 & 23.14 & 42.82 & 55.92 & $\underline{48.89}$ & 51.92 \\
\hline Fuji Select & 1.10 & 7.92 & 20.88 & 30.29 & $\underline{29.74}$ & 34.49 \\
\hline Fuji Suprema & 2.75 & 29.55 & $\underline{24.27}$ & 45.76 & $\underline{36.39}$ & 43.76 \\
\hline Gala Real & 4.31 & 16.07 & 41.10 & $\underline{39.42}$ & $\overline{64.83}$ & $\underline{45.51}$ \\
\hline Maxi-Gala & 3.89 & 13.11 & 51.42 & 46.82 & 75.58 & 53.19 \\
\hline Mishima & 1.07 & 8.26 & 28.82 & $\overline{37.55}$ & 38.63 & $\overline{53.09}$ \\
\hline Royal Gala & 4.24 & 10.17 & 37.86 & 38.68 & 62.87 & $\underline{49.54}$ \\
\hline
\end{tabular}

* Underlined values highlight drop in yield compared with the previous harvest. 
Table 2: Biennial bearing index (BBI) of apple cultivars (mean of three replications) in the harvests 2008 to 2013, in Vacaria, RS. 2017

\begin{tabular}{lcc}
\hline \multirow{2}{*}{ Cultivar } & Rootstock & Marubakaido/M-9 \\
\cline { 2 - 3 } & M-9 & $0.347 \mathrm{a}^{*}$ \\
\hline Baigent & $0.276 \mathrm{~b}^{*}$ & $0.348 \mathrm{a}$ \\
Mishima & $0.265 \mathrm{~b}$ & $0.333 \mathrm{a}$ \\
Maxi-Gala & $0.319 \mathrm{~b}$ & $0.332 \mathrm{a}$ \\
Fuji Select & $0.300 \mathrm{~b}$ & $0.306 \mathrm{~b}$ \\
Cripps Pink & $0.260 \mathrm{~b}$ & $0.296 \mathrm{~b}$ \\
Gala Real & $0.307 \mathrm{~b}$ & $0.282 \mathrm{~b}$ \\
Royal Gala & $0.279 \mathrm{~b}$ & $0.259 \mathrm{~b}$ \\
Daiane & $0.273 \mathrm{~b}$ & $0.310 \mathrm{~b}$ \\
Fuji Suprema & $0.380 \mathrm{a}$ &
\end{tabular}

Coefficient of variation $(\%)$

12.4812 .48

* Means followed by the same small letter in the column are not significantly different by the Scott-Knott test, at 5\% error probability.

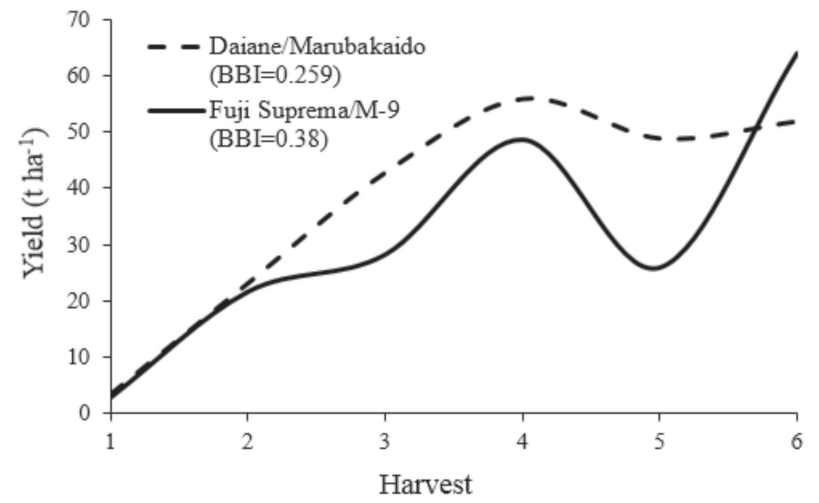

Figure 1: Mean yield $\left(\mathrm{t} \mathrm{ha}^{-1}\right)$ of cultivar Daiane on Marubakaido/ M-9 and cultivar Fuji Suprema on M-9 rootstock, the combinations with the least and the greatest tendency to alternate production, respectively.

to the Gala group, and are not considered as alternate (Robinson, 2008). However, according to Monselise \& Goldschmidt (1982), the alternate behavior can vary from place to place and the reasons for the cultivars to perform differently as a function of the cultivation site are unknown.

The Gala cultivars showed BBI ranging from 0.28 to 0.35 and the Fuji from 0.26 to 0.38 , that is, the index had similar ranges. Considering that both groups have different behavior for alternate production, according to the literature, it was expected that the BBI of the Fuji cultivars were higher and/or that the indices of the Gala cultivars were lower, showing more pronounced differences. Milatoviæ \& Duroviæ (2012) obtained indices of 0.17 and 0.26 for the cultivars Royal Gala and Gala Must and of 0.49 and 0.55 for the Fuji Naga-fu 6 and Fuji Naga-fu 2, i.e., bellow those from this study for cultivars Gala and superior for cultivars Fuji. Crassweller et al. (2005) estimated indices of 0.57 and 0.59 for Gala Supreme and Fuji, that is, higher than the values found in this study for all cultivars Gala and Fuji.
Crassweller et al. (2005) discusses that indices above 0.6 indicate a strong tendency to alternate production, which was not found for any cultivar in the six harvests evaluated. Flower and/or fruit thinning is considered a fundamental management practice to reduce the intensity of production alternation in apple trees (Bukovac et al., 2006), especially when carried out in the year of high production (Tromp, 2000). The results of this study confirm that this practice reduced the tendency to alternate production of the most sensitive cultivars, bringing them closer to the less sensitive cultivars. This is very important for assuring regular production every year and good sized fruits, and for avoiding unbalanced relationship between production and vegetative growth of the plant.

The pure correlation between the BB index and the measure of plant vigor, using the trunk cross-sectional area (TCA) from the last harvest obtained from the experimental design model, was not significant $(p>0.05)$ for any of the rootstocks. The scatter plot of the points representative of the simultaneous response of BBI and TCA shows the lack of correlation between them (Figure 2). In contrast, Barritt et al. (1997) found stronger alternation for the cultivars Golden Delicious and Granny Smith on vigorous rootstocks and for the cultivar Redchief Delicious on dwarfing rootstocks.

According to Jonkers (1979), less vigorous rootstocks can inhibit biennial bearing. These rootstocks accelerate the end of branch growth in vigorous cultivars, reducing the importance of the vegetative sink, which would lead to the export of a greater amount of assimilates to sustain the productive sinks (Barritt et al., 1997). Therefore, there is a higher proportion of spur bearers in plants grafted on less vigorous rootstocks compared to plants on vigorous rootstocks and, hence, more consistent annual productions. However, in less vigorous cultivars, the limitation of branch growth due to the influence of less vigorous rootstocks can increase biennial bearing tendencies. 

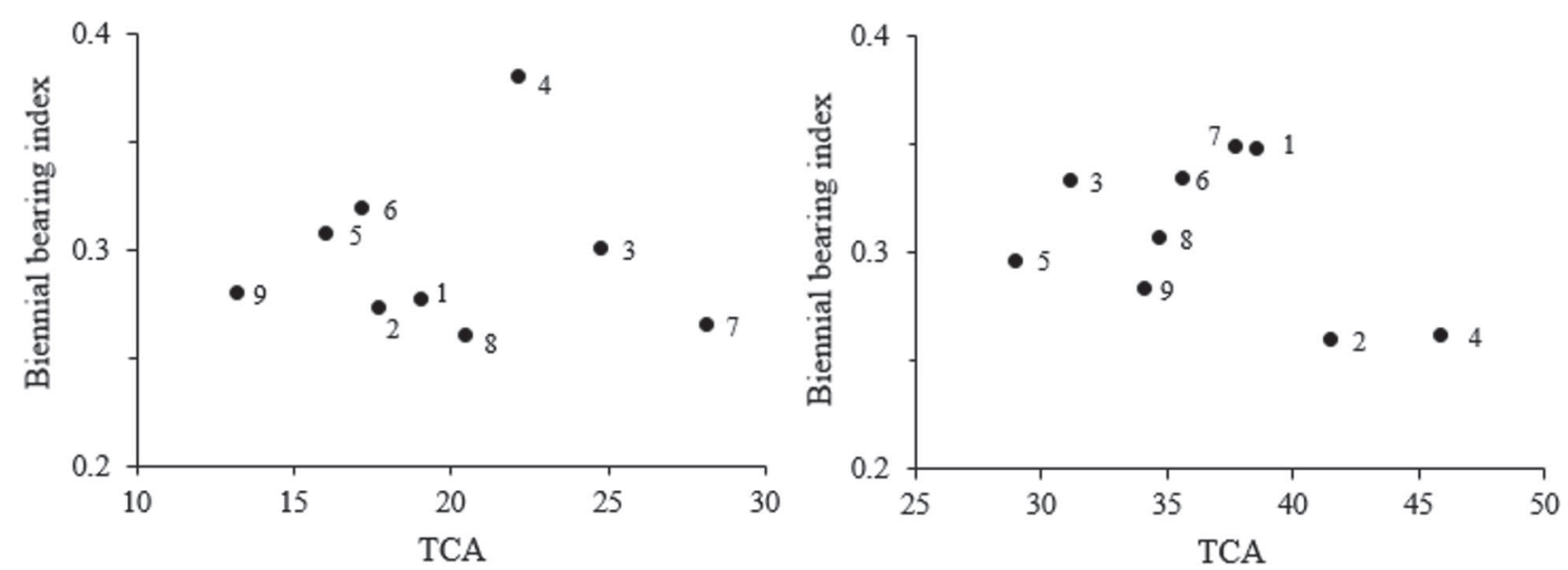

Figure 2: Scatter plot of TCA x BBI points (mean per cultivar) for the cultivars tested on rootstocks M-9 (left) and Marubakaido/ M-9 (right). Cultivar legend: Baigent (1), Daiane (2), Fuji Select (3), Fuji Suprema (4), Royal Gala (5), Maxi-Gala (6), Mishima (7), Cripps Pink (8), Royal Gala (9).

\section{CONCLUSIONS}

The apple cultivars tested in this study have no strong tendency to biennial bearing under conventional management in Vacaria, RS.

Apple cultivars form different groups regarding alternate bearing depending on the rootstock used. The combination Fuji Suprema/M-9 exhibits greater tendency to biennial bearing than the other cultivars on the same rootstock. The cultivars Baigent, Mishima, Fuji Select, and Maxi-Gala show a more alternating behavior than others when grafted on Marubakaido/M-9.

Biennial bearing index is an indicator that can be obtained under experimental design conditions and it satisfies the assumptions of the analysis of variance.

The characteristic alternate production is not associated with plant vigor in the scion-rootstock combinations tested.

\section{REFERENCES}

Bangerth KF (2000) Abscission and thinning of young fruit and their regulation by plant hormones and bioregulators. Plant Growth Regulation, 31:45-59.

Barritt BH, Konishi BS \& Dilley MA (1997) Tree size, yield and biennial bearing relationship with 40 apple rootstocks and tree scion cultivars. Acta Horticultural, 451:105-112.

Bukovac M, Sabbatini P \& Schwallier P (2006) Modifying alternate bearing of spur-type 'Delicious' apple with ethephon. HortScience, 41:1606-1611.

Cantuarias-Avilés T, Mourão Filho F de AA, Stuchi ES, Silva SR da \& Espinosa-Núñez E (2011) Horticultural performance of 'Folha Murcha' sweet orange onto twelve rootstocks. Scientia Horticulturae, 129:259-265.

Cantuarias-Avilés T, Mourão Filho F de AA, Stuchi ES, Silva SR da \& Espinosa-Núñez E (2010) Tree performance and fruit yield and quality of 'Okitsu' Satsuma mandarin grafted on 12 rootstocks. Scientia Horticulturae, 123:318-322.
Crassweller R, Clemens J, Brown S, Cowgill W, Cline J, Berkett L, Azarenko A, McNew R, Belding R \& Barritt B (2005) Performance of apple cultivars in the 1995 NE-183 regional project planting: I growth and yield characteristics. Journal of the American Pomological Society, 59:18-27.

Ferreira DF (2011) Sisvar: a computer statistical analysis system. Ciência e agrotecnologia, 35:1039-1042.

Guitton B, Kelner JJ, Velasco R, Gardiner SE, Chagné D \& Costes E (2012) Genetic control of biennial bearing in apple. Journal of Experimental Botany, 63:131-149.

Hampson CR \& Kemp H (2003) Characteristics of important commercial apple cultivars. In: Ferree DC \& Warrington IJ (Eds.) Apples: botany, production and uses. Cmbridge, CABI Publishing. p.61-89.

Hoblyn TN, Grubb NH, Painter AC \& Wates BL (1936) Studies in biennial bearing. I. Journal of the American Pomological Society, 14:39-76.

Jackson D (2011) Flowers and fruit. In: Jackson DI, Looney NE, Morley-Bunker M \& Thiele GF (Eds.) Temperate and subtropical fruit production. $3^{\mathrm{a}}$ ed. Cambridge, CABI. p.34-43.

Janick J, Cummins JN, Brown SK \& Hemmat M (1996) Apples. In: Janick J \& Moore JN (Eds.) Fruit breeding. New York, John Wiley \& Sons. p.01-77.

Jonkers H. (1979) Biennial bearing in apple and pear: a literature survey. Scientia Horticulturae, 11:303-307.

Komatsu H (1998) Red Fuji in Japan - choosing the best strain for your business strategy. Compact Fruit Tree, 31:44-45.

Krasniqi AL, Damerow L, Kunz A \& Blanke MM (2013) Quantifying key parameters as elicitors for alternate fruit bearing in cv. 'Elstar' apple trees. Plant Science, 212:10-14.

Mcartney S, Greene D, Schmidt T \& Yuan R (2013) Naphthaleneacetic acid and ethephon are florigenic in the biennial apple cultivars Golden Delicious and York Imperial. HortScience, 48:742-746.

Milatoviæ D \& Duroviæ D (2012) Growth and yield characteristics of new apple cultivars. Journal of Pomology, 46:77-82.

Monselise SP \& Goldschmidt EE (1982) Alternate bearing in fruit trees. Horticultural Review, 4:128-173.

Petri JL, Denardi F \& Suzuki A (1997) Epagri, 405-Fuji Suprema: nova cultivar de macieira. Agropecuária Catarinense, 10:48-50. 
Robinson T (2008) Crop load management of new high-density apple orchards. New York Fruit Quarterly, 16:3-7.

SAS Institute Inc. (2002) SAS OnLineDoc 9.1.3 Help and Documentation. Cary, Statistical Analysis System Institute. CD ROM
Smith HM \& Samach A (2013) Constraints to obtaining consistent annual yields in perennial tree crops. I: heavy fruit load dominates over vegetative growth. Plant Science, 207:158167 .

Tromp J (2000) Flower-bud formation in pome fruits affected by fruit thinning. Plant Growth Regulation, 31:27-34. 